\title{
LOGISTICS COLLABORATION SOLUTIONS TO IMPROVE SHORT FOOD SUPPLY CHAIN SOLUTION PERFORMANCE
}

\author{
Nsamzinshuti, $\mathrm{A}^{1} ;$ Janjevic, $\mathrm{M}^{1} ;$ Rigo, $\mathrm{N}^{1}$ and Ndiaye $\mathrm{AB}^{1}$ \\ ${ }^{1}$ Qalinca Labs, Brussels School of Engineering Université Libre de Bruxelles, Brussels, Belgium
}

\begin{abstract}
In recent years, new forms of consumption alternative to conventional food systems have emerged across the world. These consumption patterns advocate consumption of local products, quality and the distribution with maximum one intermediary between the producer and the consumer or ideally nil. The objective of these consumption patterns, which is distributed through short food supply chain, is to reduce the externalities caused by conventional consumption modes. Many authors have shown, through analysis of case studies that the consumption of local products is not reducing automatically the negative externalities. The short food supply chain still faces many challenges in order to constitute a real alternative to the globalized food model. Among these challenges, the logistics is currently the main bottleneck for the development of this sector. The logistics become even more complex when it occurs in urban areas.

The objective of this paper is to understand the specificities and the constraints of the short food supply chain in order to design suitable logistic solutions to improve short food supply chain performance.
\end{abstract}

Keywords: local food system, short food system, performance

\section{Introduction}

Over the last few years, the conventional food system has been subject to much criticism. The criticisms include the negative impact of this system on the environment and on health, fears about food security, and the low pay of small-scale farmers (T. Bosona, 2013; Green \& Phillips, 2014). In addition, consumers are demanding greater quality and traceability (Bantham \& Oldham, 2003; T. G. Bosona $\&$ Gebresenbet, 2011). In recent years, new forms of consumption that are alternatives to the conventional food system have emerged across the world. Interest in local food has increased significantly. Kneafsey et al., 2013) cites a recent survey of European consumers, $90 \%$ of respondents (26,713 respondents) agreed to buy more local food (DG AGRI, 2011). However, more than half noted the difficulty of obtaining such products.

The objective of these alternative modes of consumption, which are distributed through the short food supply chain, is to reduce the externalities caused by conventional consumption modes. These new patterns allow consumers and producers to build relationships of trust (Policy Commission, 2002). It also supports small-scale farmers to diversify production, increasing value added, and ensuring more stable incomes. However, many authors have shown through analysis of case studies that the consumption of local products is not automatically reducing the negative externalities (Martinez, 2010; Mastronardi, Marino, Cavallo, \& Giannelli, 2015; Renting et al., 2003) and did not contribute to improve economic and social performance. Some authors argue that this is because the local food system is characterised by small business with limited resources in terms of finance and knowledge. The short food supply chain still faces many challenges in order to constitute a real alternative to the globalised food model: the cost of logistics, the difficulty of complying with regulations, the difficulty to meet the requirements of customers in terms of quality, responsiveness, product availability and administrative burdens, etc. Among these challenges, 
logistics is currently the main bottleneck for the development of this sector (Ljungberg, Juriado, \& Gebresenbet, 2013). Logistics becomes even more complex in urban areas. The conventional food chain has shown that logistics was a lever to improve supply chain performance. To optimise logistics, it has long since adopted the best practices such as third-party logistics solutions, Just-In-Time delivery, supply chain integration and electronic communication systems, transportation coordination, route optimisation and logistics integration (T. G. Bosona \& Gebresenbet, 2011; Engelseth, 2016; Lacombe, 2013; Ljungberg et al., 2013).

\section{Research question}

The objective of this paper is to understand the specificities and the constraints of the short food supply chain and then, identify and analyse existing logistics collaboration solutions. From this research, authors propose a framework with a key factors to consider in setting up an effective collaborative system for short food supply chain.

This article will be organised as follows: first, the article focuses on reviewing literature on local food systems and the short food supply chain. This literature review allows us to understand the concept and the constraints of short food supply chain. Second, the paper identifies and describes collaboration logistic solutions applied in local food systems through desk research and semi-structured interviews conducted with stakeholders involved in the short food supply chain. Finally, the paper proposes a framework to establish an effective logistics collaboration in short food supply chain.

\section{Literature review}

\section{Definition of short food supply chain and local food systems}

Presently, there is no consensus regarding the exact definition of local food systems among academics, practitioners and politicians (Abate-Kassa \& Peterson, 2011; Blanquart et al., 2010; Duault, 2014a; GONCALVES \& ZEROUAL, 2014; Kneafsey et al., 2013). Several definitions of local food systems coexist in the literature. In this section, three main definitions are detailed, one based on the geographical location, the other on the number of intermediaries and the last on the proximity between the producer and the consumer.

\section{Geographical location}

This definition of the local food system focuses mainly on the geographical aspect of production and consumption, which must take place in the same area (Kneafsey et al., 2013). The main criticism of this definition is the fact that there is no consensus regarding geographical radius. This varies from 20 to $100 \mathrm{~km}$ depending on the region, the population density, but also the type of products. For fresh and perishable products, the distance must be as small as possible to ensure freshness and food safety (EC, 2013; Kneafsey et al., 2013; Martinez, 2010). Some other authors propose to use administrative delimitation such as the region, country, state and province rather than distance (Pinchot, 2014). In Anglo-Saxon countries, we often find reference of 100 miles, referring to movement 100-miles Diet (Merle \& Mathilde, 2011).

\section{Number of Intermediaries}

Some authors define a local food system as a system by which the distribution is made with a supply chain composed by a maximum of one intermediary. This supply chain is called « Short food supply chain » (Marsden, Banks, \& Bristow, 2000; Renting et al., 2003). This definition involves defining the concept of intermediaries. Some stakeholders such as logistics service providers do not see themselves as intermediaries since they do not own the products. (Marsden et al., 2000). This definition does not address the fact that the products were produced in a defined radius, but that the products have sufficiently clear and complete information on the area of production (producer, origin, quality, ect...). The quality of the product is more important than the geographical area of production. The reduced number of intermediaries guarantees consumers better reliability of such information.

\section{Relationship between consumers and producers (proximity)}

Other authors use the concept of "proximity between producers and consumers"to define a local food system. This concept of proposes a vision based on 
the existing relationship between producers and consumers. Prigent-Simonin (2012), proposed four dimensions to define the concept of proximity. (1) Geographic proximity: In addition to the notion of distance, they also cite the concept of time and ease of access. (2) Identity proximity: share the same values as the producers (protection of biodiversity, environmental protection, support small farmers). (3) Relational proximity: Exchange of product information, production and processing methods. (4) Process proximity: Knowledge of food production reinforces consumer's thoughts of product quality.

This research will adopt the definition of the local food system as a system in which, the distances and intermediaries are reduced as much as possible while keeping in mind the importance of the area of production, but also the need to establish social relationships between producers and consumers.

\section{Potential Benefit of short food supply chain}

Many benefits of local food systems have been identified in numerous studies (CoR, 2011). These benefits were observed in a social, economic as well as environmental dimension. (CoR, 2011; Kneafsey et al., 2013; Malandrin \& Dvortsin, 2015)

\section{Social benefits of local food systems}

There are many social benefits associated with the emergence of local food systems. These benefits include improving social cohesion between producers and consumers, maintaining local farms, contributing to the development of local employment, promotion of the farming profession, improving the welfare of farmers and the independence of farmers. Nevertheless, some studies also show that the local food system can lead to a form of social exclusion. The local food system does not reach the entire population especially for the population who receive a low income. The high price of local food is the main cause (Duault, 2014b; Kneafsey et al., 2013)(Chiffoleau, Gauche, \& Ollivier, 2013). (Brown et al ; 2009 Macias 2008).

\section{Economic benefits of local food systems}

Many studies have highlighted the economic impact of the development of the local food system. It has been shown through the multiplier effect that the local economy is boosted by the development of a local food system by increasing revenues of producers and creating local jobs (Pinchot, 2014). Buying locally increases sales, which has the effect of increased spending on other local sectors (transport, shopping and tourism). Finally, in the employment sector, jobs are created either directly in the agricultural sector or in other sectors (transport, local shops and commodities).

A study on the potential for job creation in the region of Brussels (Belgium) estimated that the development of a local food system in the Brussels-Capital Region could lead to the creation of more than 7000 jobs in the food sector (approximately 3000 currently) (Verdonck, Taymans, Chapelle, Dartevelle, \& Zaoui, 2014).

\section{Environmental benefits of local food systems}

The environmental benefits refer to the efforts put in place to reduce the ecological footprint of food in a region. It is recognised that the food industry is responsible for numerous environmental externalities. Several studies have shown that the production process is the one that generates the most impact in terms of emissions of greenhouse gases (57\%) compared to $17 \%$ for the distribution process, which can be higher if non-optimisation of distribution (low fill rate, empty returns, storage, ect...) is taken into account (Duault, 2014a).

The results of the environmental benefits of local food systems are highly variable depending on the products analysed, the agricultural mode, transportation mode, the data used, but also the scope of the study (Edwards-Jones et al., 2008). Some authors believe that the local food system reduces environmental impact through the reduction of GHG (Van Hauwermeiren et al. 2007; Pelletier et al. 2011) while others estimated that it has no positive effect on the environment due to the low volume (Kneafsey et al., 2013), (Duault, 2014a). Moreover, Lacombe, (2013) highlights that empty returns of trucks, consumer movements to the point of sale and the increase of cold rooms for many local food system does not allow stakeholders to significantly reduce GHG. These inefficiencies result primarily from the absence of formal logistics and a lack of optimisation of logistics activities (Blanquart et al., 2010). 
As shown in the literature, there are real benefits to the development of a local food system, but it is not always obvious to highlight these benefits due to lack of accurate data. The impact assessment carried out on a social, economic and environmental level shows that better optimisation of logistics is a key factor to improve performance for the short food supply chain.

\section{Methodologies}

To identify collaboration logistic solutions in the short food supply chain, two approaches were used: First, a "top-down" approach which consists of identifying in the literature, logistics solutions applied in short food supply chains. Second, a "Bottom-up" approach which consists of analysing local food initiatives in order to highlight logistics practices. These tasks will provide an overview of the existing logistics solutions in the short food supply chain.

\section{Scope of the study}

This study focuses only on logistics activities dedicated to the distribution of finished food products from the producer to the consumer. This implies that this study will not focus on upstream harvesting activities. The main reason is that these activities come under agronomy studies. In addition, this study does not cover food processing activities. The reason is the existence of the great diversity of practices. This study will focus on the finished product released from the food processors. Case study analysis and interviews with stakeholders will be mainly based on the European experience of local food systems with a special focus on Belgium and France.

\section{Stakeholders description}

Before analysing the logistics solutions applied in the short food supply chain, this article identifies the main stakeholders in the sector. It is proposed to group the stakeholders of local food into four categories: (1) Shippers (2) Intermediaries (3) Third Party logistics and (4) Receivers. There are other stakeholders involved indirectly in the short food supply chain, for example public authorities (regulations, laws), regulatory agencies (regulations, controls), research centres (Research \& Development), financial institutions (financing). Despite the importance of these actors, they are not the subject of analysis in this paper (Nomathemba,
2010)(Schiefer, 2011)(Christy, Mabaya, Mutambatsere, \& Mhlanga, 2009).

\section{Shippers}

By definition, shippers are stakeholders who entrust their own product to other stakeholders to ensure delivery to the final destination. In the SFSC, they are all stakeholders who produce local food. These are commonly called "producers".

Among the producers, it is possible to distinguish local farmers (mainly vegetable producers and fruit growers), livestock farmers (poultry, meat and fish) and processors (bakers, beverages and dairy products) (Chandrasekaran \& Raghuram, 2014; Rao, 2006; Srinivas, Ramanathan, Ayireddy, Taneja, \& Sitaram, 2009). Included in this category are producer cooperatives.

\section{Intermediaries}

Intermediaries are defined as stakeholders who make purchases from producers and resell them to other stakeholders (mainly business customers). In the local food system, intermediaries are mainly food wholesalers or distributors (Dooley \& Foltz, 2012).

\section{Receivers}

By definition, receivers are stakeholders who receive food products they ordered from producers or wholesalers. Trienekens \& al., (2008) indicate that their position gives them some power over other supply chain stakeholders in the sense that they have access to crucial information about the needs of end consumers. In this category, there are, for example, Community-supported agriculture groups (CSA), grocery stores, conventional supermarkets, restaurants and collective restaurants.

\section{Third Party Logistics}

These stakeholders offer logistics services (inventory, transport, order management, ect...) to other companies. In the SFSC, the logistics service providers pay particular attention to offering services that meet the needs of this sector by providing ecofriendly services (low-emission vehicles, recyclable 
packaging, cyclocargo, ect...) with a positive social impact and tailored to small business.

\section{Typologies of short food supply chain}

In a SFSC, consumers are reached through different distribution channels. In this work, the classification proposed by Chiffoleau et al., (2013) is adopted. This classification is based on the one hand, on either the absence or presence of an intermediary between the producer and consumer, respectively direct and indirect distribution. Then, the authors distinguish within each category, an individual or collective dimension of the distribution. Four distribution channels of local food systems are identified each distribution channel has very specific characteristics, challenges and needs in terms of logistics organisation (Aubry, Bressoud, \& Petit, 2011).

\section{Direct Distribution - individual}

This category includes all the direct distribution to the end consumers ( e.g. Farmers' Markets, Internet sales and individual baskets). The volumes sold through this distribution are generally quite low. Consumers who buy through this channel mainly want to meet producers and know more about the production process. This is for them a guarantee of good quality products. There are no formal logistics for this type of distribution.

\section{Indirect Distribution - individual}

This channel provides local food to consumers through collective organisations. (Consumer or producer organisations). This channel of distribution generates greater volumes since there is a scale effect in the grouping of orders by those organisations.
Receivers in this channel are looking to buy a wider range of local products at a more affordable price. Moreover, they expect some flexibility in terms of distribution according to their availability (evenings or weekends). Logistics activities in this channel are relatively informal and characterised by high inefficiency (Aubry et al., 2011).

\section{Indirect distribution - individual}

This type of distribution is performed through intermediaries who sell local products to the final consumers. Those intermediaries are mainly stores, grocery stores, supermarkets and wholesalers. The final consumers who buy local food through this channel are looking for good quality products and need to be regularly supplied to prevent stock-outs. The retail sector is more demanding regarding the respect of delivery schedules to ensure complex planning in this sector.

\section{Indirect distribution - collective}

This is a distribution channel via collective intermediaries as HORECA and collective restaurants (private and public canteens). These intermediaries require large volumes, a wide range of products and at low prices (Bresson, 2012). Moreover, they require from producers, very strict compliance with food hygiene standards. In terms of logistics performance, regularity and punctuality of deliveries are needed to prepare meals on time. Table 1 shows the characteristics of each distribution channel in terms of volume, product diversity, flexibility, logistics and the purchase price (Duault, 2014a).

Table 1: Characteristics of local food system distribution channel (Adapted from Duault, 2014a)

\begin{tabular}{|l|l|l|l|l|l|}
\hline \multicolumn{2}{|l|}{ Distribution Channel } & Volume & Diversity & Flexibility & Price \\
\hline \multirow{2}{*}{ Direct Distribution } & Individual & Low & High & High & High \\
\cline { 2 - 6 } & Collective & Mid & High & High & Mid \\
\hline \multirow{2}{*}{ Indirect Distribution } & Individual & Mid & Mid & Mid & Mid \\
\cline { 2 - 6 } & Collective & High & Low & Low & Low \\
\hline
\end{tabular}


Collaboration logistics solutions used in short food system

Below the paper proposes an analysis of the various collaborationlogistic solutions used in the SFSC. These solutions have been identified in the literature and from discussions with the stakeholders of the local food system.

Much research has already been carried out on the potential for collaboration to improve logistics in the short food supply chain (BLANQUART, Gonçalves, Raton, \& Vaillant, 2015; Duault, 2014a). This research has clearly shown interest in collaboration in terms of cost reduction, reduction of externalities and the impact on competitiveness (Christopher, 1999). Case analysis of a logistics collaborative study on the conventional supply chain was able to show that it is possible to reduce on average $30 \%$ of logistics costs (Guinouet, Jordans, \& Cruijssen, 2012; Lacombe, 2013).

The surveys of farmers show that they are generally reluctant to collaborate. The main reasons include lack of trust between stakeholders, fear of loss of their independence, singularity of their distribution network, lack of tools and cost-sharing methods (BLANQUART et al., 2015; Duault, 2014a).

There are two types of collaboration: (1) horizontal collaboration in which several players, having the characteristics, as competitors, collaborate in order to improve overall logistics performance of each actor involved in this collaboration (collaboration in increasing purchasing volumes and infrastructure sharing). (2) Vertical collaboration which is between the actors within the same supply chain. This mainly concerns the sharing of information between the actors involved in this collaboration (Ozener, 2008).

\section{Horizontal collaboration between producers}

In the literature there are several forms of collaboration between producers. This collaboration mainly covers sharing of logistics infrastructure (vehicles, storage and management tools).

Logistics facilities sharing can be done in several processes (storage, transport and sales). The main reason for sharing logistics facilities is the underutilisation of available capacity and the high- cost investment and management of these facilities (Gonzalez-Feliu \& Morana, 2011).

\section{Collaborative Warehouse}

Storage is a critical process in logistics performance. It is one of the largest sources of costs in the supply chain. It is estimated to represent $20 \%$ to $30 \%$ of costs through the cost of ownership of inventory. This is especially important when it concerns perishable products that require temperature-controlled storage conditions. Moreover, improved inventory management avoids stockouts and thereby improves customer satisfaction. Sharing storage space is a collaboration solution that enables actors to reduce costs and improve the supply chain performance of actors involved. There are many forms of storage space sharing (cross-dock, regional platforms, urban consolidation centres or urban logistics spaces). Nevertheless, Gonzalez-Feliu \& Morana (2011) stress the importance of the availability of reliable, updated and complete information as a key success factor of a logistics partnership and as well as trust between actors involved in the collaboration.

In local food systems, inventories can be found at all levels of the supply chain, from the producer (storage of harvested products) to point of sale (storage of products to sales). Given the cost and complexity associated with managing a stock, more collaboration solutions have emerged. Two main practices were identified. First, the producer who offers to other producers their unused storage space. This is usually a form of informal collaboration between producers who are located in the same region and know one another very well. The second solution is the sharing of storage space belonging to a cooperative. This collaboration for storage has the advantage of reducing inventory and compliance costs (MESSMER, 2013).

\section{Collaboration in the Transport and distribution system}

The main benefit of transport collaboration is increasing vehicle fill rates and thus reducing transport costs (Ozener, 2008). Transportation and distribution management remain the most expensive and complicated process for the actors of the SFSC. Some studies show that these processes can represent over $40 \%$ of turnover, while on average in the food 
sector they are more than $10 \%$ to $15 \%$ (Raton et al., 2015). Many actors, especially farmers, do not calculate the costs of transport (MESSMER, 2013). Therefore, they have no idea of these costs, so they cannot undertake this process. To improve transport performance, collaboration is the solution most cited in the literature. On average a $30 \%$ reduction in kilometres travelled compared to individual transport is observed (Lacombe, 2013). There are many forms of collaboration in transport for producers. These range from sharing a vehicle under-exploited with other producers to the joint purchase and management of a vehicle by a farmers' cooperative (BLANQUART et al., 2015).

\section{Sharing a Vehicle}

Sharing a vehicle involves using a vehicle belonging to a farmer to transport products from other farmers. Either a farmer makes a tour to get products from other farmers or everyone brings products to the farmer-carrier. This type of collaboration requires effective organisation and the implementation of costsharing methods to avoid potential conflicts and ensure sustainability of this system. Moreover, this system is only possible for farmers who are in the same area and are confident enough to avoid competition problems.

When a third person transports goods that do not belong them, it is a transport for hire or reward. This type of transport is governed by most national legislation (Regulation (EC) No 1071/2009 and the Belgium Law of 15 July 2013). To avoid administrative burdens and encourage collaboration, an exemption has been established for the local food system. This allows producers to transport products to third parties without profit (they can request compensation to cover the costs), without complying with transportation regulations related to transport for hire or reward (AFSCA, 2015a). Special attention should be given to the transportation of incompatible products. The regulations required to ensure effective separation so that there is no risk of cross contamination during transportation.

\section{Jointly purchase a vehicle}

This form of transport under collaboration consists of the acquisition of a transport vehicle by a cooperative or group of farmers. In France and Belgium, this form of jointly purchased agricultural equipment is called CUMA (Coopérative d'Utilisation de Matériel). One of the main advantages is that this collaboration can benefit from public aid. In the Wallonia Region (Belgium), this aid is equal to $25 \%$ of eligible investments (Wallonie Élevages, 2012).

At the organisational level, farmers can use the vehicle in turn or go further by hiring a driver as in the case of CUMA "Terroirs sur la route" in the Loire-Atlantique in France. This CUMA acquire a truck and hire an employee driver for the transport of goods of farmers who are members of this CUMA (Terroirs44, 2016)(Lacombe, 2013). The latter organisation is more complicated to implement, because it requires a management system to be set up taking into account the constraints of each member. Other advantages are: a faster return on investment, the offloading of transport activities for the farmer (if the CUMA hires a driver). However, to succeed, lessons learned from other experiences show that it is necessary to establish information flow management systems to establish precise timetables and vehicle usage monitoring. This avoids conflicts of use and results in better cost allocation.

\section{Horizontal collaboration between producers}

From the receiver's side, there are also different forms of logistics collaboration. This collaboration takes place mainly on sourcing processes. In this process, the collaboration focuses on the management of orders and storage of products received from suppliers (producers, processors or wholesalers).

\section{Storage}

Receivers must ensure the storage of products they receive until consumers come to take or buy them. The management of storage space and more particularly a refrigerated storage represents high costs. Pooling of storage spaces reduces storage costs for receivers, but also facilitates the work of producers who can deliver to one delivery point. From this deposit point, other receivers can pick up their products with eco-friendlier means of transport (cycling and walking). This type of collaboration has the advantage of reducing costs related to the management and total cost of ownership. Moreover, delivery of the last mile is facilitated by the grouping 
of products in one place. However, this collaboration is only possible with good coordination between receivers and setting up tools to share costs and risks.

\section{Order management}

Collaboration on order management involves pooling orders in order to reduce the costs of placing orders. Some actors involved support small producers, such as groups of CSA, through this collaboration the market improves for producers. This solution contributes to reducing administrative tasks related to orders.

\section{Transport}

Some receivers like shops, grocery stores...pick up the products themselves because producers don't have means of transport or that because the order quantity is not sufficient for the producer to make the delivery. Receivers can organise to pool the transportation of products they buy from the same producer.

\section{Vertical collaboration between stakeholders}

As explained above, vertical collaboration occurs when stakeholders in the same supply chain collaborate. This collaboration involves the sharing of information of logistics flows to improve logistics performance. In local food systems, information shared focuses on consumer demand, producers' offers and information about the distribution network.

\section{Consumers' demand}

In terms of demand, some producers use internet (websites, social media, ect...) to gather and understand consumers' needs. These systems have the advantage of being easy to use for consumers (Lacombe, 2013). Consumers groups like CSA, establish long-term contracts with producers. Members of these groups order products in advance for periods ranging from 3 to 6 months. This practice also allows the producer to ensure stable income for a greater period of time.

\section{Producers' offer}

To improve their market opportunities, producers are marketing their products on the internet (website, social media) to a greater extent. On these platforms, consumers can find product descriptions, prices and sometimes an online payment system. While these tools are easy to use for consumers, they represent an investment for the installation, maintenance, and time to regularly update the website. To overcome these issues, several businesses have emerged. They offer common online marketplaces and allow reduced costs and reach a larger number of consumers. "la Ruche qui dit OUI", "topino" and "Efarmz" are some examples. Despite the benefit related to the sharing of these catalogues, some criticise these initiatives due to the lack of transparency in the margins applied, but also the lack of commitment to ensure stable revenues for the producers (De La Héronnière, 2016).

\section{Sharing of information related to distribution network}

The sharing of information on the distribution network (customers, orders, tours, date and frequency of deliveries) allows better visibility of logistics flows and facilitates logistics collaboration between local food system's stakeholders. This type of data sharing is more complicated to implement because it involves sensitive information which can constitute a competitive advantage. Substantial work in upstream is needed in order to raise awareness of the benefits of sharing these types of information and establish a reliable platform that allows stakeholders to share information safely. The "Open Food Network" platform is an example that proposes a system in which producers, food hubs and consumers can share information in order to stimulate logistics collaboration. 
Table 2: Overview of logistics collaboration solutions from the literature review

\begin{tabular}{|c|c|c|c|}
\hline & Type & Solution & Examples \\
\hline \multirow{3}{*}{$\begin{array}{l}\text { Vertical } \\
\text { collaboration }\end{array}$} & Consumer's demand & website, Social media, & Farmer's websites and social media \\
\hline & Producer's offers & marketplaces, websites & $\begin{array}{l}\text { Ruche qui dit Oui (BE, FR); Topino } \\
\text { (BE); Efarmz (BE) }\end{array}$ \\
\hline & Logistics information's & digital platform & OpenFood Network (AU, FR, UK,...) \\
\hline \multirow{7}{*}{$\begin{array}{l}\text { Horizontal } \\
\text { collaboration }\end{array}$} & \multirow{4}{*}{ Between producers } & collaborative warehouse & Agricovert (BE) \\
\hline & & $\begin{array}{l}\text { transport and distribution } \\
\text { collaboration }\end{array}$ & Association Manger-Fermier (FR) \\
\hline & & sharing vehicle & n.a \\
\hline & & jointly purchased vehicle & Cuma des Terroirs Mayennais (FR) \\
\hline & \multirow{3}{*}{ Between receivers } & sharing storage space & Heureux Nouveau (BE) \\
\hline & & bulk purchase & GASAP (BE) \\
\hline & & transportation collaboration & Beescoop (BE) \\
\hline
\end{tabular}

\section{Analysis of logistics solutions}

Table 2 shows the analysis of the relevance of each logistic solution with respect to different distribution channels. Horizontal collaboration between producers $(\mathrm{HC} / \mathrm{P})$ is a solution that requires a lot of coordination, but could meet the needs of all distribution channels, especially in direct distribution where logistics facilities (vehicles and stock) are underused due to low volume or inefficiency of logistics. Horizontal collaboration between receivers is suitable for consumers or consumer groups (CSA) because the issues related to confidentiality or competition are lower in these categories. Vertical collaboration (VC) is an appropriate solution for all distribution channels. The sharing of information is important to enable all other collaboration solutions. However, to share information in an efficient manner, a reliable information system is needed.

This paper is aware that this analysis based on classification provided by (Chiffoleau et al., 2013) can obscure details of some specific actors who have special needs such as sales through the internet platform such as «Ruche qui dit $O U I »$, the distribution of the HORECA and distribution to supermarkets. These are important and need to be considered in future research, particularly through quantitative and qualitative surveys of stakeholders of local food systems. From the collected data, a multicriteria and multi-actor analysis is required to confirm the analysispresented in this article but also to quantify the relevance of the solutions according to each actor.
Table 3: Relevance of logistics solutions regarding the distribution channel (+Adequate, +++ Very Adequate, , +++ Strongly Adequate)

\begin{tabular}{|c|c|c|c|c|}
\hline & & H.C/P & H.C/R & V.C \\
\hline \multirow{2}{*}{$\begin{array}{c}\text { Direct } \\
\text { distribution }\end{array}$} & $\begin{array}{l}\text { Individual (e.g. : } \\
\text { Baskets...) }\end{array}$ & +++ & +++ & ++ \\
\hline & Collective (e.g.: CSA..) & +++ & ++ & +++ \\
\hline \multirow[b]{2}{*}{$\begin{array}{c}\text { Indirect } \\
\text { distribution }\end{array}$} & $\begin{array}{l}\text { Individual (e.g. : } \\
\text { Grocery..) }\end{array}$ & ++ & + & +++ \\
\hline & $\begin{array}{l}\text { Collective (e.g.: } \\
\text { HORECA...) }\end{array}$ & ++ & + & +++ \\
\hline
\end{tabular}

\section{Collaboration framework in the short food supply} chain

This analysis has been used in the "Choud'Brussels project" which is a research project supported by the Brussels Region. It's aimed to set up a collaborative logistics solutions suit for distribution of local food in the Brussels-Capital Region in order to reduce logistics costs as well as the negative impact of transportation activities in Brussels. So far, several meetings and workshops were held with stakeholders. The first results have highlighted the main key factors to consider in setting up an effective collaborative system especially between producers.

\section{Vertical collaboration key factors}

The main difficulty encountered in the exchange of information between stakeholders in short food supply chain is the lack of knowledge of producers in the usage of digital solutions. Indeed, since they are at the origin information flows, it is important that they provide reliable information to other stakeholders in the supply chain. Today, as demonstrated the analysis of this paper, producers are 
led to manage a multitude of tools to exchange information with other stakeholders (marketplaces, telephones, mail, websites, social media...). In order to set up an effective information exchange system, producers need a tool which allows to centralize all information flow (orders, deliveries, availability of products, etc.). Moreover, to facilitate the adoption of such a tool, it must include other functionalities which help producers to manage its internal processes (Forecasting, delivery management, returns management, ...). However, this tool should not be an additional burden for producers, but rather a means of reducing administrative tasks (standardized information and documents).

In addition, particular attention must be paid to the usability of this tool. Indeed, due to the fact that producers are not used to digital solutions and don't want to spend more time in the handling of this tool, it is essential to design this tool as user-friendly as possible.

\section{Horizontal collaboration key success factors}

In our investigation, we noticed that several local producers were willing to collaborate but did not know how to identify the right partner. This is due to a lack of visibility and a lack of information exchange between producers. At the same time, producers have expressed their need to keep control of their processes and also a lack of confidence in others producers.It is therefore important to build bonds of trust between potential partners.

In Choud'Bruxelles project, an intermediate phase has been planned. its consists of designing the collaboration during which partners learn to know each other, their needs as well as their constraints. At the end of this phase, a collaboration agreement is established. This agreement must contain answers to all partners' questions relating to collaboration such as the purpose of collaboration, duration, organization, sharing costs and risks associated with the collaboration. To establish this agreement, tools must be made available to potential partners in order to validate this agreement. These tools can be simulation tools to assess the accuracy of the agreement in terms of cost sharing, compliance with the planning... When a collaboration agreement has been found, it can be implemented. Finally, it is necessary to monitor collaboration through predefined performance indicators.

\section{Conclusion and further research}

The local food system, which has many advantages in social, economic and environmental aspects, is characterised by a very low level of logistics performance. This research highlighted the existence of many logistics practices in the short food supply chain from informal to advanced ones. Among these solutions, some are more suited to certain distribution channels due to the particular constraints and needs of each distribution channel identified in this research. However, it is necessary to go further in identifying the characteristics, needs and constraints of the local food systems' actors to better design effective logistic solutions.

This research also identified the opportunity for the collaboration solutions as a key to improve logistics performance of the short food supply court and the need to share information through an effective vertical collaboration between the actor.

This research should go further in quantifying performance logistics solutions regarding to key performance indicators. Moreover, to assess the relevance of these solutions to different distribution channels, multi-criteria and multi-actor analysis should be conducted.

\section{References}

Abate-Kassa, G., \& Peterson, H. C. (2011). Market Access for Local Food through the Conventional Food Supply Chain. International Food and Agribusiness Management Review, 14(1).

AFSCA. Circulaire relative à la vente de denrées alimentaires du producteur au consommateur, avec l'intervention d'un tiers pour l'organisation de la livraison, PCCB/S3/EME/1310092 (2015).

AFSCA. (2015b, December). Groupements d'achats Quelles sont les règles? Agence fédérale pour la Sécurité de la Chaîne alimentaire.

Aubry, C., Bressoud, F., \& Petit, C. (2011). Les circuits courts en agriculture revisitent-ils l'organisation du travail dans l'exploitation? Le Travail En Agriculture: Son Organisation et Ses Valeurs Face à L'innovation.

Bantham, A., \& Oldham, C. (2003). Creating value through traceability Solutions. Illinois, USA: FoodOrigins. 
Barham, J., Tropp, D., Enterline, K., Farbman, J., Fisk, J., \& Kiraly, S. (2012). Regional Food Hub Resource Guide (Research Reports No. 145227). United States Department of Agriculture, Agricultural Marketing Service, Transportation and Marketing Program.

BLANQUART, C., Gonçalves, A., Raton, G., \& Vaillant, L. (2015). Vecteurs et freins d'une logistique plus durable dans les circuits courts : le cas du Nord - Pas-de-Calais. In ASRLDF. Montpellier, France.

Blanquart, C., Gonçalves, A., Vandenbossche, L., Kebir, L., Petit, C., \& Traversac, J.-B. (2010). The logistic leverages of short food supply chains performance in terms of sustainability. In W. C. on T. R. Society (Ed.), 12th World Conference on Transport Research (p. 10p). Lisbonne, Portugal.

Bosona, T. (2013). Integration of logistics network in local food supply chains (Vol. 2013).

Bosona, T. G., \& Gebresenbet, G. (2011). Cluster building and logistics network integration of local food supply chain. Biosystems Engineering, 108(4), 293-302.

Bresson, A. (2012). Les conditions favorables aux circuits courts destinés à la restauration collective hors domicile. Bordeaux: Sciences Agro.

Chandrasekaran, N., \& Raghuram, G. (2014). Agribusiness Supply Chain Management. CRC Press.

Chiffoleau, Y., Gauche, A., \& Ollivier, D. (2013). Impacts sociaux des circuits courts alimentaires sur les exploitations agricoles: diversité des midèles et analyses croisées.

Christopher, M. (1999). Logistics and Supply Chain Management: Strategies for Reducing Cost and Improving Service Financial Times: Pitman Publishing. London, 1998 ISBN $027363049 \quad 0$ (hardback) 294+1\$ltimes\$ pp.

Christy, R., Mabaya, E., Mutambatsere, E., \& Mhlanga, N. (2009). Enabling environments for competitive agro-industries. In Agro-industries for development, (pp. 136-185). Wallingford, UK.

CoR. (2011). Opinion of the Committee of the Regions on "Local food systems" (outlook opinion) (2011/C 104/01). Official Journal of the European Union.

De La Héronnière, L. (2016, December 1). Tout sur La Ruche qui dit oui!: ses avantages, ses inconvénients, la différence avec une Amap. Retrieved September 20, 2016,

DG AGRI. (2011). Special Eurobarometer 368: The Common Agricultural Policy. Brussels: DirectorateGeneral for Agriculture and Rural.

Duault, A. (2014a). Evaluating sustainable logistics for Local Food Systems and using colaboration as a tool for rationnalization in the retail-wholesale sector: A case study in the Nord-Pas de Calais region, France. 130.

Duault, A. (2014b). Evaluating sustainable logistics for Local Food Systems and using colaboration as a tool for rationnalization in the retail-wholesale sector: A case study in the Nord-Pas de Calais region, France. 130.

EC. (2013). Report from the commission to the european parliament and the council on the case for a local farming and direct sales labelling scheme. Brussels: EUROPEAN COMMISSION.

Echo. (2016). agriculture. L'Echo.

Edwards-Jones, G., Milà i Canals, L., Hounsome, N., Truninger, M., Koerber, G., Hounsome, B., ... Jones, D. L. (2008). Testing the assertion that "local food is best": the challenges of an evidence-based approach. Trends in Food Science \& Technology, 19(5), 265274. https://doi.org/10.1016/j.tifs.2008.01.008

Engelseth, P. (2016). Developing Exchange in Short Local Foods Supply Chains. International Journal on Food System Dynamics, 7(3), 229-242.

GONCALVES, A., \& ZEROUAL, T. (2014). Les circuits courts alimentaires: vers une logistique plus verte? In RIODD 2014 (p. 13p). France.

Gonzalez-Feliu, J., \& Morana, J. (2011). Collaborative transportation sharing: from theory to practice via a case study from France, 252-271.

Green, G. P., \& Phillips, R. G. (2014). Local Food and Community Development. Routledge.

Guinouet, A., Jordans, M., \& Cruijssen, F. (2012, November). CO3 case study: Retail Collaboration in France. Presented at the CO3 Projet.

HUAN, S., SEORAN, S., \& WANG, G. (2004). A review an analysis of supply chain operations reference (SCOR) model. Supply chain management. An International Journal, 9(1), 23-29.

Kneafsey, M., Venn, L., Schmutz, U., Balázs, B., Trenchard, L., Eyden-Wood, T., ... Blackett, M. (2013). Short food supply chains and local food systems in the EU. A state of play of their socioeconomic characteristics. JRC Scientific and Policy Reports. Joint Research Centre Institute for Prospective Technological Studies, European Commission.

Kurnia, S., Hill, S., Rahim, M. M., Larsen, K., Braun, P., \& Samson, D. (2016). Open Food Network: the Role of ICT to Support Regional Food Supply Chains in Australia. arXiv:1606.01456 [cs].

Lacombe, C. (2013). Organiser la collaboration logistique dans les circuits alimentaires de PROXIMITE : quelle place pour le réseau Cuma et la coopération agricole de production? Ecole Supérieure d'Agriculture d'Angers. 
Lindner, C., Cui, L., \& Hertz, S. (2009). Supply Chain Performance Measure ment: A research of occurring problems and challenges (MasterThesis). Jönköping International Business School.

Ljungberg, D., Juriado, R., \& Gebresenbet, G. (2013). Conceptual model for improving local food supply chain logistics. In Proceedings of the 13th World Conference on Transport Research.

Malandrin, V., \& Dvortsin, L. (2015). Eating from the farm: the social, environmental and economic benefits of local food systems. Friends of the Earth Europe.

Malhotra, R., \& Temponi, C. (2010). Critical decisions for ERP integration: Small business issues. International Journal of Information Management, 30(1), 28-37.

Marsden, T., Banks, J., \& Bristow, G. (2000). Food supply chain approaches: exploring their role in rural development. Sociologia Ruralis, 40(4), 424-438.

Martikainen, A., Niemi, P., \& Pekkanen, P. (2014). Developing a service offering for a logistical service provider-Case of local food supply chain. International Journal of Production Economics, 157, 318-326.

Martinez, S. (2010). Local food systems; concepts, impacts, and issues. Diane Publishing.

Mastronardi, L., Marino, D., Cavallo, A., \& Giannelli, A. (2015). Exploring the Role of Farmers in Short Food Supply Chains: The Case of Italy. International Food and Agribusiness Management Review, 18(2), 109.

Merle, A., \& Mathilde, P. (2011, July 11). Consommer des produits alimentaires locaux : comment et pourquoi? Retrieved from http://hal.grenoble-em.com/hal-00607840/document

MESSMER, J.-G. (2013). Les circuits courts multiacteurs: Emergence d'organisations innovantes dans les filières courtes alimentaires. INRA.

Morganti, E., \& Gonzalez-Feliu, J. (2015). The Last Food Mile Concept as a City Logistics Solution for Perishable Products. In thieu Lauras, rtin Zelm, B. Archimède, F. Bénaben, \& G. Doumeingts (Eds.), Enterprise Interoperability (pp. 202-207). John Wiley \& Sons, Inc.

Nomathemba, M. (2010). Développement de l'agribusiness, Finance et investissement agricoles (No. 27). FAO.

Nsamzinshuti, A. (2016). Choud'bruxeles Project. Retrieved from http://cocreatebruxsel.be/rubrique7.html

Nsamzinshuti, A., \& Ndiaye, A. B. (2014). Designing a hospital performance measurement system (HPMS) based on SCOR Model. In The 2nd IEEE
International Conference on Logistics Operations Management 2014, 2 (pp. 347-359).

Olson, D. L., \& Staley, J. (2012). Case study of opensource enterprise resource planning implementation in a small business. Enterprise Information Systems, 6(1), 79-94.

Ozener, O. O. (2008). Collaboration in transportation. ProQuest.

Pinchot, A. (2014). The Economics of Local Food Systems: A literature review of the production, distribution, and consumption of local food. College of Food, Agriculture, \& Natural Resource Sciences.

Policy Commission. (2002). Farming and food: a sustainable future: report of the Policy Commission on the Future of Farming and Food. London, England.

Prigent-Simonin, A. H. (2012). Au plus près de l'assiette: pérenniser les circuits courts alimentaires. Editions Quae.

Rao, K. L. (2006). Agro-industrial parks experience from India. Agricultural and Food Engineering Working Document, 3.

Raton, G., Gonçalves, A., Vaillant, L., Blanquart, C., Loeuilleux, P., \& Tellier, C. (2015). ALLOCIRCO Alternatives logistiques pour les circuits courts en Nord - Pas de Calais. Villeneuve d'Ascq: IFSTTAR.

Renting, H., Marsden, T. K., \& Banks, J. (2003). Understanding Alternative Food Networks: Exploring the Role of Short Food Supply Chains in Rural Development. Environment and Planning A, 35(3), 393-411.

Rokicki, T., \& Wicki, L. (2011). Evaluation of Scope of Using the Information Systems Depending on Sector of Agribusiness. Information Systems in Management. E-Logistics and Computer Aided Logistics, 77-85.

RWDR. (2014, September 19). Innovation en agriculture: Compte-rendu de la journée d'échanges et des visites de terrain en Flandre 19 septembre 2014. Réseau wallon de Développement Rural.

SCC. (2012). Supply Chain Operations Reference Model. Version, 11.

Schiefer, G. (2011). Transparency in Food: A Challenge for Research and Sector Initiatives. International Journal on Food System Dynamics, 02(2).

Siegenthaler, M., \& Estève, M. (2014). Plateformes dans la restauration collective: organiser l'offre de produits locaux (Marchés et filières). Lausanne: Agridea.

Srinivas, R., Ramanathan, A., Ayireddy, V. L., Taneja, S., \& Sitaram, P. (2009). CONSUMER MARKETS Food processing and Agri business. Mumbai: KPMG in India. 
Terroirs44. (2016). Terroirs44. Retrieved from http://www.terroirs44.org/

Trienekens, J., \& al. (2008). Assessment of innovation and performance in the fruit chain The innovation-performance matrix. British Food Journal, 110, 98-127.Turban, E., \& Volonino, L. (2012). Information technology for management: transforming organizations in the digital economy. Hoboken $(\mathrm{NJ})$ :
J.

Wiley.
Verdonck, M., Taymans, M., Chapelle, G., Dartevelle, G., \& Zaoui, C. (2014). Système d'alimentation durable, Potentiel d'emplois en Région de Bruxelles-Capitale, (p. 103). Brussels: Centre d'études régionales bruxelloises - Facultés Universitaires Saint-Louis and Greenloop.

Wallonie Élevages. (2012). Les coopératives. Un modèle ringard ou une voie d'avenir? (No. $\mathrm{N}^{\circ} 11$ ). 